\title{
EFFECT OF SULPHUR, GYPSUM AND COMPOST ADDITION AND TILLAGE METHODS ON SOIL PROPERTIES AND WHEAT PRODUCTIVITY IN SALINE SOIL
}

\author{
M. A. A. Esmaeil \\ Soils, Water and Environ. Res. Inst., Agric. Res. Center, Giza, Egypt. \\ Received: Mar. 8,2018 \\ Accepted: Apr. 17, 2018
}

\begin{abstract}
Effective use of salt affected soils needs the development of the most efficient and suitable reclamation technology to optimize farm management and better crop yields. Different chemical methods and amendments are used to reclaim the salt affected soils, and after reclamation such soils may be used for sustainable agricultural production. Choice of a chemical amendment depends on its availability, cost, handling and time of application. A field experiment was conducted for two successive winter seasons 2014/2015 and 2015/2016 at Sahl El-Hossinia Agric. Res. Station, El-Sharkia Governorate, Egypt, to evaluate two tillage methods (surface and subsurface) and three soil amendments (elemental sulphur "S", gypsum "Gy", compost "Co", compost + sulphur, compost + gypsum, gypsum + sulphur and compost + sulphur + gypsum) on some soil properties and wheat yield. The studied treatments were arranged within the experimental units in a split plot design in three replicates. Statistical analysis of grains and straw yield data showed that all the added amendments significantly increased the grains and straw yield of wheat compared with control. The addition of $\mathrm{Gy}+\mathrm{Co}+\mathrm{S}$ was the most effective addition in increasing the grains and straw yield in surface and subsurface tillage. Also, it is clear that grains and straw yields of wheat in the treatments of subsurface tillage were slightly higher than those in the treatments of surface tillage. Data showed that all applications of soil amendments under different tillage methods decreased soil $\mathrm{pH}$ and EC, but there is an increase in the values of organic matter and cation exchange capacity. This effect is more obvious in case of applying $\mathrm{Gy}+\mathrm{Co}+\mathrm{S}$. Subsurface tillage associated by high values of O.M (\%) and CEC (c.mole) than surface tillage. Soil OM (\%) and CEC (c.mol/kg) were significantly increased as a result of added amendments. Data showed that values of total dry stable aggregates (DSA) and water stable aggregates (WSA) were increased in all treatments under study compared to control. The highest increase in values of total stable aggregates (DSA and WSA) was observed in the treatment of $\mathrm{Gy}+\mathrm{Co}+\mathrm{S}$ with subsurface tillage method compared to the treatments of surface tillage method and control. The highest values of hydraulic conductivity, total porosity, field capacity and available water were found by applying $G y+C o+S$ treatment in subsurface tillage method compared to control and other treatments of surface and subsurface tillage. The values of soil bulk density at different soil depths of all treatments were relatively low and the maximum decrease exists in case of the treatment $\mathrm{Gy}+\mathrm{Co}+\mathrm{S}$ with subsurface tillage method compared to other treatments and control. Generally, it can be concluded that gypsum, sulphur and compost application had decreased the hazardous effect of salinity of soil and hence exerted favorable effects on growth and yield of wheat. Subsurface tillage method improved soil chemical and physical properties which are reflected on growth and grain yield of wheat compared with the surface tillage method.
\end{abstract}

Key words: Sulphur, Gypsum, Compost, Wheat productivity and Saline soil. 


\section{INTRODUCTION}

Among environmental stresses, soil salinity is one of the most important threats to sustainable agriculture of arid and semi-arid regions of world. Salt affected soils occupy wide regions scattered all over the world (about 954 millions hectares), (Szaboles, 1989). In meantime, salt stress is one of the most serious limiting factors for crop growth and production in arid and semi-arid regions. In Egypt, the north regions, particularly of northeastern Delta, are mainly saline or saline-sodic soils with heavy texture. El-Hossinia plain is one of the new reclaimed saline-sodic soils after drying a large area from El-Manzala Lake.

Abou El-Defan et al. (2005) studied the effect of farmyard manure, gypsum and mix of them on some characteristics of soil irrigated with drainage water. They found that both EC and ESP values significantly decreased with different treatments, especially with application of farmyard manure mixed with gypsum.

Abd Elrahman et al. (2012) stated that application of soil amendments gypsum (4.64 ton/fed), citric acid (1.31 ton/fed), farmyard manure (51.3 ton/fed), compost (71.7 ton/fed) and the combination of them decreased soil $\mathrm{pH}$ values when compared to the control. The treatment $50 \%$ gypsum $+50 \%$ compost had decreased $\mathrm{pH}$ values and increased wheat yield significantly. In general, subsurface layers $(15-60 \mathrm{~cm})$ showed higher values of soil $\mathrm{pH}$ compared with the surface one $(0-15 \mathrm{~cm})$. Moustafa (2005) found that application of gypsum reduced $\mathrm{pH}$ values in the alkali soil with maximum decrease in the upper layer (0$20 \mathrm{~cm}$ ).

Application of different amendments as gypsum, compost and farmyard manure under irrigation with drainage water caused pronounced reductions in the EC values compared to the control.
The highest effect in decreasing EC values was obtained by the treatment of $50 \%$ gypsum + $50 \%$ FYM. Generally, surface layers had lower EC values than the subsurface ones. This may be due to increasing leachability of soluble and exchangeable $\mathrm{Na}^{+}$throughout the soil profile (Abd Elrahman et al., 2012). Beheiry et al. (2005) reported that addition of organic manures decreased soil salinity and they attributed that to improving physical properties of the soil which in turn facilitate the leaching of salts outside from the root zone.

Abd Elrahman et al. (2012) found that addition of Gypsum and compost improved, relatively their chemical properties which in turn promote plants growth, improve general plant vigor and encourages their yields. The highest effect in increasing yield was obtained from the treatment $50 \%$ gypsum $+\mathbf{5 0} \%$ compost. Singh et al. (1989) reported that application of gypsum reduced $\mathrm{pH}$ and improved soil physical properties, which together were reflected on the yield and this effect was increased when gypsum combined with organic manure.

Generally, significant improvement occurred due to the use of gypsum and sulphur on saline-sodic soils as sources of $\mathrm{Ca}$ and $\mathrm{S}$. The increases in wheat yield and its contents is due to the (1) displacement of sodium by calcium, (2) decreasing soil $\mathrm{pH}$ and increasing the nutrient use efficiency of the crop, (Bello, 2012). From the above mentioned results, it can be concluded that gypsum and sulphur application decreased the hazardous effect of salinity and sodicity of both soil and irrigation water and hence exerted favorable effects on growth and nutrient contents of wheat.

Ahmed et al. (2016) studied the effect of different amendments on wheat grain and straw yield, data showed a noticeable effect of all the treatment used 
than control (no amendment). Overall mean values for grain yield $\left(3.11 \mathrm{Mg} \mathrm{ha}^{-1}\right)$ was highest in gypsum, followed by Sulfur which were statistically alike. While control led to minimum grain yield of $1.60 \mathrm{Mg} \mathrm{ha}^{-1}$, in comparison with those of applied treatments. They found a progressive increase in case of straw yield (4.73 $\mathrm{Mg} \mathrm{ha}^{-1}$ ) was computed in gypsum followed by sulphur (4.64 $\mathrm{Mg}$ ha $\left.{ }^{1}\right)$. While lowest straw yield (2.16 $\left.\mathrm{Mg} \mathrm{ha}^{-1}\right)$ was given by control.

Elemental sulfur is considered as an adequate and cost effective amendment for soda-saline soils (Tarek et al., 2013) and recommended when soil pH exceeds 6.6 for the purpose of reducing $\mathrm{pH}$ this changes in soil pH can mobilize nutrients from unavailable phases to available pools therefore increasing $P$ and micronutrient availability.

Sulphur is an essential element for plant growth as it helps in synthesis of peptides, various secondary metabolites, vitamins and chlorophyll in the cell (Abdallah et al., 2010). Plants need sulfur in same amount as phosphorus, and for the proper soil nutrient balance, optimizing crop yield and good quality produce it is very important to apply optimum amount of sulfur in the soil along with other nutrients, which are necessary for plant (Jez, 2008).

Rice-wheat crop rotation was adopted in a saline-sodic field (electrical conductivity of soil extract $=6.10 \mathrm{dS} \mathrm{m}^{-1}$, $\mathrm{pH}$ of soil saturated paste $=9.21$, and soil gypsum requirement (SGR) of $9.10 \mathrm{t} \mathrm{ha}^{-1}$ for $0-15 \mathrm{~cm}$ soil depth). The treatments included were: control, gypsum application $100 \%$ of SGR, sulfur application $25,50,75,100 \& 125 \%$ of SGR. Analysis of four-year pooled data indicated that varying levels of sulfur and gypsum significantly improved soil chemical properties and wheat yield. Results showed that sulfur at $125 \& 100 \%$ of SGR gave similar results as that of gypsum at $100 \%$ of SGR in terms of growth and yield of wheat and reducing $\mathrm{pH}$, electrical conductivity (Ahmed et al., 2017).

Hossein et al., (2017) investigated the effects of different tillage methods on some soil aggregation properties and wheat yields. The results showed that tillage methods were significant at $(P<0.01)$ as regards crop yields, and the highest yields as 6249 and $11720 \mathrm{~kg} / \mathrm{ha}$ for wheat grain and biomass were produced in sub soil tillage, respectively. Sub soil was significant at $(P<0.05)$ with $2.063 \mathrm{~mm}$ as to mean weight diameter (MWD) value. The sub soil was statistically in the same group with regard of water stable aggregates (WSA) value, and it was significant at $(P<0.05)$ with $67,83 \%$. Bulk density, total porosity and air porosity values were significant at $(P<0.05)$. Field capacity $(F C)$ and permanent wilting point (PWP) were significant at $(P<0.05)$ and $(P<0.01)$ with $31.89 \%$ and $17.21 \%$ values in the chisel treatment, respectively.

Soil tillage is among the important factors affecting soil properties and crop yield. Among the crop production factors, tillage contributes up to $20 \%$ (Khurshid et al., 2006). The judicious use of tillage practices overcomes edaphic constraints, whereas inopportune tillage may cause a variety of undesirable outcomes, for example, soil structure destruction, accelerated erosion, loss of organic matter and fertility, and disruption in cycles of water, organic carbon, and plant nutrient (Lal, 1993). Reducing tillage positively influences several aspects of the soil whereas excessive and unnecessary tillage operations give rise to opposite phenomena that are harmful to soil.

Mohammadi et al. (2013) studied the effect of three types of tillage including conventional tillage (moldboard plow to soil depth of $30 \mathrm{~cm}$ ), minimum tillage 
(chisel plow to soil depth of $15 \mathrm{~cm}$ ) and no-tillage on soil properties and wheat production. Results showed that the greatest bulk density was found in the minimum tillage and no tillage methods. The highest rate of grain yield was obtained in the minimum tillage method. Minimum tillage improved soil physical properties and wheat growth compared with the other tillage methods.

Alam et al. (2014) investigated the effects of medium-term tillage practices on soil properties and crop yields in Grey Terrace soil of Bangladesh under wheatmungbean-T. aman cropping method. Four different tillage practices, namely, zero tillage (ZT), minimum tillage (MT), conventional tillage (CT), and deep tillage (DT), were studied. Tillage practices showed positive effects on soil properties and crop yields. After four cropping cycles, the highest $O M$ accumulation, the maximum root mass density $(0-15 \mathrm{~cm}$ soil depth), and the improved physical and chemical properties were recorded in the conservational tillage practices. Bulk and particle densities were decreased due to tillage practices, having the highest reduction of these properties and the highest increase of porosity and field capacity in zero tillage. The highest BD reduction $(6.41 \%)$ was found in $\mathrm{ZT}$ followed by MT (3.95\%), while DT showed the lowest reduction. porosity was increased from the initial value $(6.2,2.9$, and $0.69 \%$ increase in $\mathrm{ZT}, \mathrm{MT}$, and $\mathrm{CT}$, resp.). The field capacity (FC) was also increased due to different tillage practices. The highest FC increase (14.65\%) was found in ZT followed by MT (8.52\%). CT showed the lowest increase of field capacity from the first year value. Permanent wilting point (PWP) was also influenced by the different tillage practices. After four years, the permanent wilting point was decreased due to tillage practices. The highest reduction (11.91\%) was found in ZT followed by CT (8.32\%) and the lowest reduction (1.13\%) in DT. the yield gap was very minimal (negligible) among different tillage practices, though the deep tillage showed the highest yield. In the case of straw yields, a similar trend was found.

Gholami et al. (2014) studied the effects of different tillage methods on some parameters such as soil salinity (pH, EC, SAR), soil density and nutrients in a nested experimental design with three treatments (no tillage, reduced tillage and conventional tillage). By changing tillage method from conventional tillage to no tillage, soil bulk density and porosity changed to a range of 1.41 to $1.29{\mathrm{gr} . \mathrm{cm}^{-3}}^{-3}$ and 47.58 to $52.45 \%$. Likewise, the no tillage had the highest electrical conductivity (1.78 decisiemens) and sodium adsorption ratio (9.22) and the lowest amount of acidity (7.65). In the case of the conventional tillage method, the lowest electrical conductivity (1.19 decisiemens) and sodium adsorption ratio (7.52) and the highest acidity (7.77) was observed. Although soil salinity and density under the conventional tillage treatment compared to the no tillage method show lower values, but it seems that improvement of the physiochemical properties of soil in the long-term approach is different from the short-term.

Wheat (Triticum aestivum L.) is the most important cereal crop in Egypt. Increasing wheat production is an essential national target to fill the gap between production and consumption, (Zeidan et al., 2009). The new goals of the Egyptian agricultural policy are to increase the local wheat production through the expansion of the cultivated area and optimization of agricultural inputs. The strategy of the Ministry of Agriculture is to increase the cultivated wheat area in the newly reclaimed lands and breeding high yielding varieties. 
Wheat cultivars differed in growth characters (EL-Habbasha et al., 2008).

The objective of the present study is to evaluate the use of two tillage methods (surface and subsurface) and three soil amendments (sulphur, gypsum and compost and their combination) in clay loam soil properties and wheat (Triticum aestivum, L.) (Masr, 2) productivity under newly reclaimed saline soil conditions.

\section{MATERIALS AND METHODS}

A field experiment was conducted for two successive winter seasons 2014/2015 and 2015/2016 at Sahl ElHossinia Agric. Res. Station, El-Sharkia Governorate, Egypt, located at $31^{\circ} 8^{\prime}$ $12.461 " \mathrm{~N}$ latitude and $31^{\circ} 52$ ' $15.496 " \mathrm{E}$ Longitude, to evaluate the use effect of two tillage methods (surface and subsurface) and three types of soil amendments (sulphur, gypsum and compost and their combination) on clay loam soil properties and wheat (Triticum aestivum, L.) (Masr, 2) productivity under newly reclaimed saline soil conditions.

In both seasons, each experiment was carried out in a split plot design with three replicates. The tillage methods (surface and subsurface) were treated as main plots, while the treatments of sulphur, gypsum and compost and their combination were distributed at random in the sub plots. The experimental area was one faddan $\left(4200 \mathrm{~m}^{2}\right)$ which divided into two divisions representing tillage methods, surface and subsurface. Each division was divided into eight units plots representing the treatments of:

1- Control "C".

2- Elemental sulphur "S" 4.0 ton/ fed.

3- Gypsum "Gy" 4 ton/ fed.

4- Compost "Co" 4 ton/ fed.

5- Compost "Co" 2 ton/fed + sulphur "S" 2.0 ton/fed.
6- Compost "Co" 2 ton/fed + gypsum "Gy" 2 ton/fed.

7- Gypsum "Gy" 2 ton/fed + sulphur "S" 2.0 ton/fed.

8- Compost "Co"2 ton/fed + sulphur "S" 2.0 ton/fed + gypsum "Gy" 2 ton/fed.

So, the experiment units were 48 plots, where the area of each plot was 87 $\mathrm{m}^{2}(10 \times 8.7 \mathrm{~m})$. Wheat grains (Masr 2) were sown at 25 of November 2014 and 2015. The grains of wheat (Masr 2) were obtained from Crop Research Institute, Agriculture Research Center, Giza, Egypt. Different treatments of soil amendments were carried out before planting by 25 days and mixed with the surface soil (0$15 \mathrm{~cm}$ ). El-Salam Canal (Nile water mixed with agricultural drainage water 1:1) was irrigation water resource in the studied area.

Before planting, surface soil samples $(0-30 \mathrm{~cm})$ of the studied area were taken, air dried, ground, mixed and sieved through a $2 \mathrm{~mm}$ sieve. Some physical and chemical properties of the sieved soil sample were carried out according to the methods described with the soil samples taken after plant harvesting, and the obtained data were recorded in Table (1). The main properties of both compost and irrigation water were carried out as described by Richards (1954) and the obtained data were recorded in Tables (2 and 3).

Calcium super phosphate (15.5\% $\mathrm{P}_{2} \mathrm{O}_{5}$ ) was added at $200 \mathrm{~kg}$ calcium super phosphate/fed during soil preparation. Urea $(46 \% N)$ was used as $N$ fertilizer at application rate of $100 \mathrm{~kg} \mathrm{~N} / \mathrm{fed}$, where it's applied in 3 equal doses after 21, 45 and 60 days of planting. Potassium sulphate $\left(48 \% \quad \mathrm{~K}_{2} \mathrm{O}\right)$ at $70 \mathrm{~kg} / \mathrm{fed}$ was added on two equal doses after 21 and 45 days of planting. Wheat crop was harvested at 15 may 2015 and 20 may 2016. 
Table (1): Physical and chemical properties of the studied soil before planting

\begin{tabular}{|c|c|c|c|c|c|c|c|}
\hline $\begin{array}{c}\text { Coarse sand } \\
(\%)\end{array}$ & $\begin{array}{c}\text { Fine } \\
\text { sand } \\
(\%)\end{array}$ & $\begin{array}{c}\text { Silt } \\
(\%)\end{array}$ & $\begin{array}{c}\text { Clay } \\
(\%)\end{array}$ & $\begin{array}{c}\text { Texture } \\
\text { class }\end{array}$ & $\begin{array}{c}\text { O.M } \\
(\%)\end{array}$ & $\begin{array}{c}\text { CaCO }_{3} \\
(\%)\end{array}$ & $\begin{array}{c}\text { CEC } \\
\text { C } \\
\text { mol/kg } \\
\text { soil }\end{array}$ \\
\hline 6.37 & 24.96 & 33.52 & 35.15 & Clay Loam & 0.46 & 7.50 & 36.65 \\
\hline $\begin{array}{c}\text { pH } \\
(1: 2.5)\end{array}$ & $\begin{array}{c}\text { EC } \\
(\mathrm{dS} / \mathrm{m})\end{array}$ & $\begin{array}{c}\text { B.D } \\
\left(\mathrm{g} / \mathrm{cm}^{3}\right)\end{array}$ & $\begin{array}{c}\text { T.P } \\
(\%)\end{array}$ & \multicolumn{3}{|c|}{ Soil moisture constants (\%) } \\
\hline 8.12 & 9.12 & 1.55 & 41.51 & F.C. & W.P. & \multicolumn{3}{c|}{ A.W. } \\
\hline \multicolumn{8}{|c|}{ Dry aggregates diameter (mm) } \\
\hline $10-2$ & $2-1$ & $1-0.50$ & $0.50-0.25$ & $0.25-0.125$ & $0.125-0.063$ & $<0.063$ \\
\hline 50.32 & 25.35 & 11.54 & 7.08 & 1.21 & 3.00 & 1.50 \\
\hline \multicolumn{7}{|c|}{ Wet aggregates diameter (mm) } \\
\hline $10-2$ & $2-1$ & $1-0.50$ & $0.50-0.25$ & $0.25-$ & $0.125-0.063$ & Total (TSA) \\
\hline 6.00 & 3.00 & 11.00 & 6.22 & 4.18 & 2.62 & 33.02 \\
\hline
\end{tabular}

$\mathrm{BD}=$ Bulk density Average of real density $\left(\mathrm{g} / \mathrm{cm}^{3}\right)=2.65$ T.P. $=$ Total porosity. F.C = Field Capacity. A.W = Available Water. W.P = Wilting Point.

Table (2): Main properties of the compost used in the experiment

\begin{tabular}{|c|c|c|c|c|c|c|c|c|}
\hline $\mathrm{EC}(\mathrm{dS} / \mathrm{m})$ & $\begin{array}{c}\mathrm{pH} \\
(1: 5)\end{array}$ & $\begin{array}{c}\text { (1:10) } \\
\text { (Manure: } \\
\text { water extr.) }\end{array}$ & $\begin{array}{c}\text { Bulk } \\
\text { (Manure: } \\
\text { water sus.) }\end{array}$ & $\begin{array}{c}\text { Water } \\
\left(\mathrm{g} / \mathrm{m}^{3}\right)\end{array}$ & $\begin{array}{c}\text { Wolding } \\
\text { capacity } \\
(\%)\end{array}$ & $\begin{array}{c}\text { O.M } \\
(\%)\end{array}$ & $\begin{array}{c}\mathrm{C} / \mathrm{N} \\
\text { ratio }\end{array}$ & \multicolumn{3}{|c|}{ Total nutrients $(\%)$} & $\mathrm{N}$ & $\mathrm{P}$ & $\mathrm{K}$ \\
\hline 5.76 & 7.25 & 0.35 & 160 & 37.69 & 13.1 & 1.83 & 0.88 & 2.23 \\
\hline
\end{tabular}

Table (3): Irrigation water properties

\begin{tabular}{|c|c|c|c|c|c|c|c|c|c|c|}
\hline \multirow{2}{*}{ pH } & \multirow{2}{*}{$\begin{array}{c}\mathrm{EC} \\
\mathrm{dS} / \mathrm{m}\end{array}$} & \multicolumn{4}{|c|}{ Cations } & \multicolumn{4}{|c|}{ Anions } & \multirow{2}{*}{ SAR } \\
\hline & & $\mathrm{Ca}^{2+}$ & $\mathrm{Mg}^{2+}$ & $\mathrm{Na}^{+}$ & $\mathrm{K}^{+}$ & $\mathrm{Cl}^{-}$ & $\mathrm{CO}_{3}{ }^{2-}$ & $\mathrm{HCO}_{3}^{-}$ & $\mathrm{SO}_{4}{ }^{2-}$ & \\
\hline 8.04 & 1.66 & 3.07 & 4.29 & 8.16 & 0.41 & 6.74 & - & 3.83 & 5.73 & 4.25 \\
\hline
\end{tabular}

\section{Soil sampling:}

After plant harvesting, undisturbed and disturbed soil samples were collected from experimental plot at each $0-30,30-60$ and $60-90 \mathrm{~cm}$ soil depth, in the two seasons. The soil samples were air dried and analyzed for some physical and chemical characteristics, i.e., soil EC $\left(\mathrm{ds} \mathrm{m}^{-1}\right), \mathrm{pH}$, organic matter, total calcium carbonate and cation exchange capacity according to the methods described by Cottenie et al. (1982). Particle size distribution was carried out by the pipette method described by Gee and Bauder (1986) using sodium hexameta phosphate as a dispersing agent. Soil bulk density was determined using the undisturbed soil column according to Richards (1954). Total soil porosity was calculated as percentage from the obtained values of real and bulk densities (Richards, 1954). Stability of dry aggregates was determined according to the method of Richards (1954). Stability 
of water stable aggregates was determined using the wet sieving technique described by Yoder (1936) and modified by Ibrahim (1964). The determination of soil moisture equilibrium values was carried out according to the methods described by Richards and Weaver (1944) and Richards (1947). Wilting point (W.P) was determined according to Stakman and Vanderhast (1962), while field capacity (F.C) was determined as described by Richards (1954).

\section{Statistical Analysis:}

The data of this study were statistically analyzed through analysis of variance (ANOVA) and least significant difference (LSD) at $\mathbf{0 . 0 5}$ probability level to make comparison among treatment means according to Gomez and Gomez (1984).

\section{RESULTS AND DISCUSSION}

1. Wheat grains and straw yields:

The effect of sulphur, gypsum and compost addition on wheat yield (grains and straw) is shown in Table (4). It can be deuced that all of the used soil amendments treatments significantly increased the grains and straw yield of wheat compared with control treatment. The addition of $\mathrm{Gy}+\mathrm{Co}+\mathrm{S}$ resulted in highest increase in grains yield which were 3.56 and 3.90 ton/fed as a mean values of two growing seasons in surface and subsurface tillage, respectively. The same addition gave also the highest increase of straw yield, where the obtained straw yields were 4.40 and 4.76 ton/fed in surface and subsurface tillage, respectively. These results are in agreement with those obtained by Bello (2012) and Ahmed et al. (2016), who observed a high increase in wheat straw and grain yields due to using sulphur and gypsum applications. Also, Abd Elrahman et al., (2012) deduced an increase in wheat grain after using compost in salt affected soil. Also, it is clear that grains and straw yields of wheat in subsurface tillage were slightly higher than those in surface tillage. This may be attributed to that using of subsurface tillage decreased $\mathrm{pH}$ and EC and improved soil physical properties which led to increase availability of nutrients and increase wheat yield. Data agree with the results reported by Hossein et al. (2017).

Table (4): Effect of tillage methods and soil amendments on yield of wheat plant (average of two seasons)

\begin{tabular}{|c|c|c|c|c|}
\hline \multirow{2}{*}{ Treatments } & \multicolumn{3}{|c|}{ Weight of grains yield (ton/fed) } & \multicolumn{2}{c|}{ Weight of straw yield (ton/fed) } \\
\cline { 2 - 5 } & \multicolumn{3}{|c|}{ Tillage method } & \multicolumn{2}{|c|}{ Tillage method } \\
\cline { 2 - 6 } & Surface & Sub surface & Surface & Sub surface \\
\hline Control "C" & $1.09 \mathrm{c}$ & $1.24 \mathrm{c}$ & $2.19 \mathrm{f}$ & $2.59 \mathrm{~h}$ \\
\hline Sulphur "S" & $1.67 \mathrm{bc}$ & $1.79 \mathrm{c}$ & $2.24 \mathrm{f}$ & $2.66 \mathrm{~g}$ \\
\hline Gypsum "Gy" & $1.69 \mathrm{bc}$ & $1.85 \mathrm{c}$ & $2.29 \mathrm{f}$ & $2.85 \mathrm{f}$ \\
\hline Compost "Co" & $1.58 \mathrm{bc}$ & $1.69 \mathrm{c}$ & $2.40 \mathrm{e}$ & $2.96 \mathrm{e}$ \\
\hline Co + S & $2.74 \mathrm{ab}$ & $2.87 \mathrm{~b}$ & $3.25 \mathrm{~d}$ & $3.19 \mathrm{c}$ \\
\hline Co + Gy & $2.69 \mathrm{ab}$ & $2.78 \mathrm{~b}$ & $3.70 \mathrm{c}$ & $3.10 \mathrm{~d}$ \\
\hline Gy + S & $3.14 \mathrm{a}$ & $3.20 \mathrm{ab}$ & $3.89 \mathrm{~b}$ & $3.98 \mathrm{~b}$ \\
\hline Gy + Co + S & $3.56 \mathrm{a}$ & $3.90 \mathrm{a}$ & $4.40 \mathrm{a}$ & $4.76 \mathrm{a}$ \\
\hline LSD 5\% & 1.283 & 0.842 & 0.110 & 0.001 \\
\hline
\end{tabular}




\section{Soil chemical characteristics:}

The presented data in Table (5) show that, with both surface and subsurface tillage methods, soil chemical properties were substantially improved as a result of soil amendments applications. This improvement in the chemical properties may be discussed in the following points:

\section{2.a. Soil pH:}

Data presented in Table (5) shows a slight decrease in $\mathrm{pH}$ values of subsurface tillage than those of surface tillage. The data of soil $\mathrm{pH}$ indicates that soil $\mathrm{pH}$ values were decreased by additions of gypsum, sulphur and compost individually and their combination compared to control under two tillage methods. The highest decrease in $\mathrm{pH}$ values (7.93 and 7.89 in surface and subsurface tillage, respectively) was noticed with the combined treatments of the used soil amendments $\left(G y+C_{0}+S\right)$. These data are in agreement with the results reported by Abd Elrahman et al. (2012), who observed a decrease in soil pH after using compost and gypsum. The positive effect of compost on improving soil chemical properties could be due to release of $\mathrm{CO}_{2}$ during the degradation process and thus decreased the precipitation of $\mathrm{Ca}^{2+}$ and $\mathrm{CO}_{3}{ }^{2-}$ ions in the $\mathrm{CaCO}_{3}$ form (Elgezairi, 2016). Gypsum could be oxidized biologically in presence of organic matter in soil to produce $\mathrm{H}_{2} \mathrm{SO}_{4}$ which react with native $\mathrm{CaCO}_{3}$ to form $\mathrm{CaSO}_{4}$ lowering the soil $\mathrm{pH}$, with well-known effects upon the availability of some nutrients in the soil, then increasing their uptake and concentrations in plants that led to increasing plant yield. These results are in agreement with those of El-Banna et al. (2004) and Moustafa (2005) who observed a decrease in soil pH after gypsum application.

In addition, with all treatments of soil amendments either with surface and subsurface tillage method, soil $\mathrm{pH}$ was increased with the increase of soil depth which in harmony with the soil content of organic matter. In this respect, El-Sanat (2003) obtained on similar results.

\section{2.b. Soil electrical conductivity (EC):}

Soil salinity after wheat harvest as affected by the used three soil amendments as given in Table (5) indicated that samples of subsurface tillage have a slight and no significance decrease in EC values than that of soil samples with surface tillage. Similar results were obtained by Rasouli et al. (2014) and El-Sanat (2003) who observed also a slight variance in EC values between different tillage methods. Data also cleared that application of such amendments significantly decreased soil EC $\left(\mathrm{dSm}^{-1}\right)$ values when compared with the control. The treatment of gypsum + compost + sulphur has the highest effect in decreasing $\mathrm{EC}$ values followed by the treatment of gypsum + sulphur, then compost + sulphur and compost + gypsum, while compost treatment has the lowest decrease in EC values compared with the other treatments of the used soil amendments. These results are in agreement with those of Ahmed et al. (2016). Gypsum application as amendment could be oxidized biologically in presence of organic matter in soil to produce $\mathrm{H}_{2} \mathrm{SO}_{4}$ which is capable to mobilize base cations from the soil. The $\mathrm{H}^{+}$ion in the acidic water displaces the cations from the exchange sites, reduces the exchangeable cations and increases the concentrations of these cations in the soil solution, hence decreasing soil EC. Similar results were obtained by Mahmoud et al., (2013).

In addition with two tillage methods and also with all applications of the tested soil amendments, soil EC slightly increased with the soil depth increase. 
This trend resulted from the soluble salts leached with irrigation water from surface layers to deeper layers. Before that, El-
Sanat (2003) obtained on similar results in salt affected soils in Northern Nile Delta.

Table (5): Chemical properties of soil as affected by different treatment under study after Wheat harvest (average of two seasons)

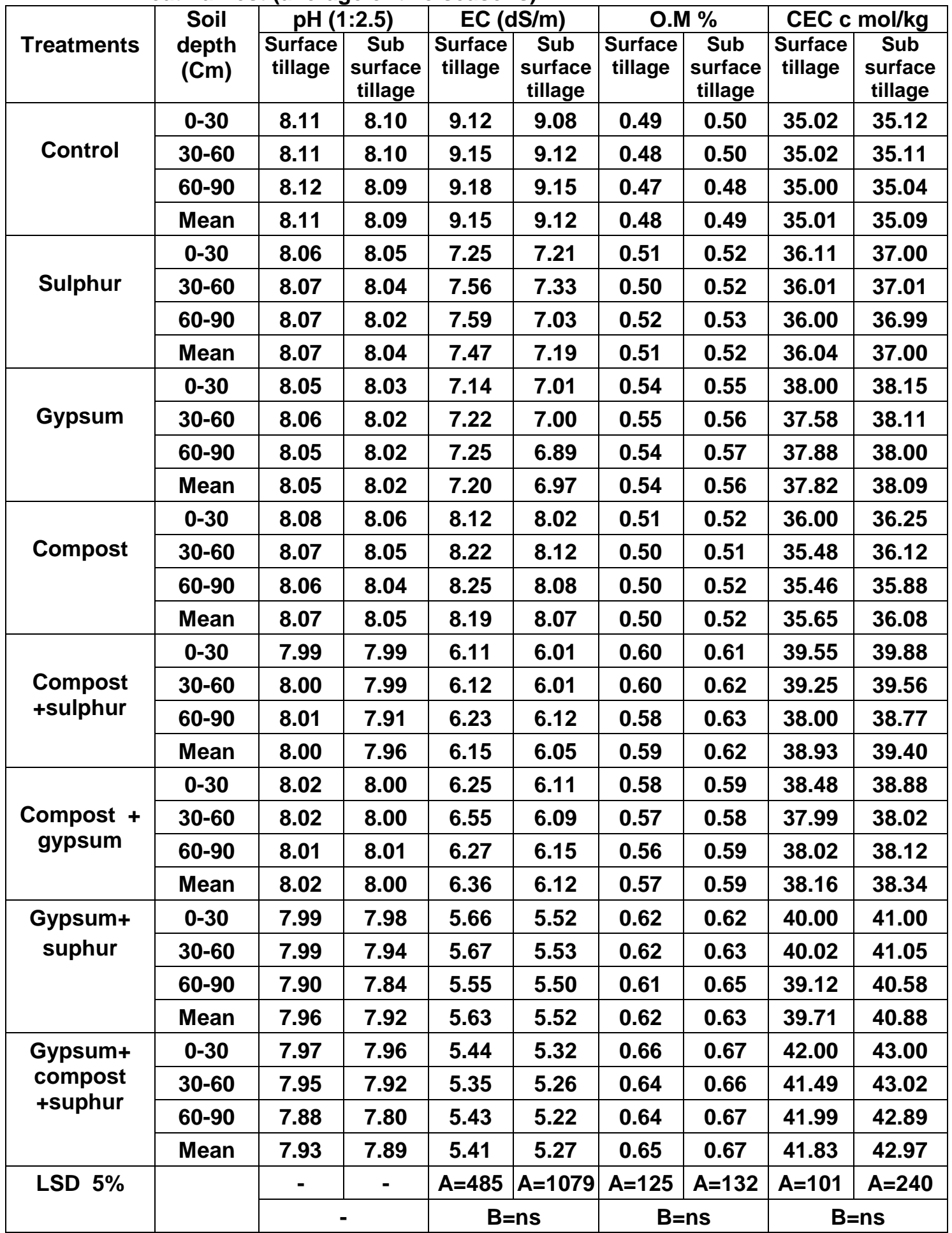

$A=$ Amendments treatments, $B=$ Tillage methods 


\section{2.c. Soil organic matter and cation exchange capacity:}

Organic matter is regarded as the ultimate source of nutrients and microbial activity in the soil. It is the deciding factor in soil structure, water holding capacity, infiltration rate, aeration and porosity of the soil. Data presented in Table (5) showed that all treatments increased the content (\%) of $O . M$ in soil under different tillage methods compared with control. Subsurface tillage produced slightly higher values of O.M than surface tillage. The highest increase in O.M values was noticed in the treatment of Gypsum + Compost + Sulphur. These results are in agreement with those of Muhammad and Khattak, (2009) who found that the application of compost resulted in overall increase of the soil organic matter level.

The cation exchange capacity of the soil as affected by all treatments took the same trend of organic matter. This may be attributed to that soil organic matter encourages granulation, increases cation exchange capacity (CEC) and is responsible up to $90 \%$ adsorbing power of the soils, (Brady and Weil, 2005). Data in Table (5) show that the CEC (c.mol/kg) was significant as affected by different fertilizer sources. The highest value of CEC was found in the treatment of Gypsum + Compost + Sulphur with values 41.83 and 42.97 in surface and subsurface tillage, respectively. EI-Maaz et al., (2014) elucidated increase in O.M and CEC values in soil after using compost as amendment or fertilizer.

\section{Soil physical properties:}

\section{3.a. Soil aggregation:}

Soil aggregation is one component of soil structure. Aggregation was clearly affected by the different treatments under study. Distribution of soil stable aggregates showed marked variations associated with different treatments. The aggregate categories studied in this experiment are of the following diameters (mm): 10-2 , 2-1 , 1-0.5, 0.5-0.25, 0.25$0.125,0.125-0.063$ and $<0.063$. For reasons of data presentation they are designated as follows: very large, large, medium, sub-medium, small, very small and extremely small, respectively. Dry aggregation covered the 7 categories, but wet aggregation (because of its nature) covered the 6 categories. Data showed marked changes in all categories. Discussion will cover the three aggregate categories of very large, sub-medium and very small aggregates as representative for the effect of treatments on aggregation.

\section{3.a.1. Dry sieved stable aggregates (DSA):}

The distribution fractions (\%) of dry sieved stable aggregates are illustrated in Table (6). It is clear that, the dominant diameters were for $10-2$ and $2-1 \mathrm{~mm}$ in surface and subsurface tillage. While $0.5-$ 0.25 and $0.125-0.063 \mathrm{~mm}$ recorded the lowest diameter weights in surface and subsurface tillage, respectively. Concerning treatments of soil amendments, there was a slight increase in weights of 10-2, 2-1 and 1-0.5 mm diameters in all treatments than control. The treatment of Gy + Co + S caused the highest increase and sulphur treatment induced the least increase. As well as, the almost of the percent of dry stable aggregates are increased with increasing the soil depth except large size aggregates which have diameters 10$2 \mathrm{~mm}$.

\section{3.a.2. Water stable aggregates (WSA):}

Table (7) contains the values of water stable aggregates (WSA \%) as well as distribution of aggregates size fractions. It can be deduced that, the mean values of aggregates having diameters between 


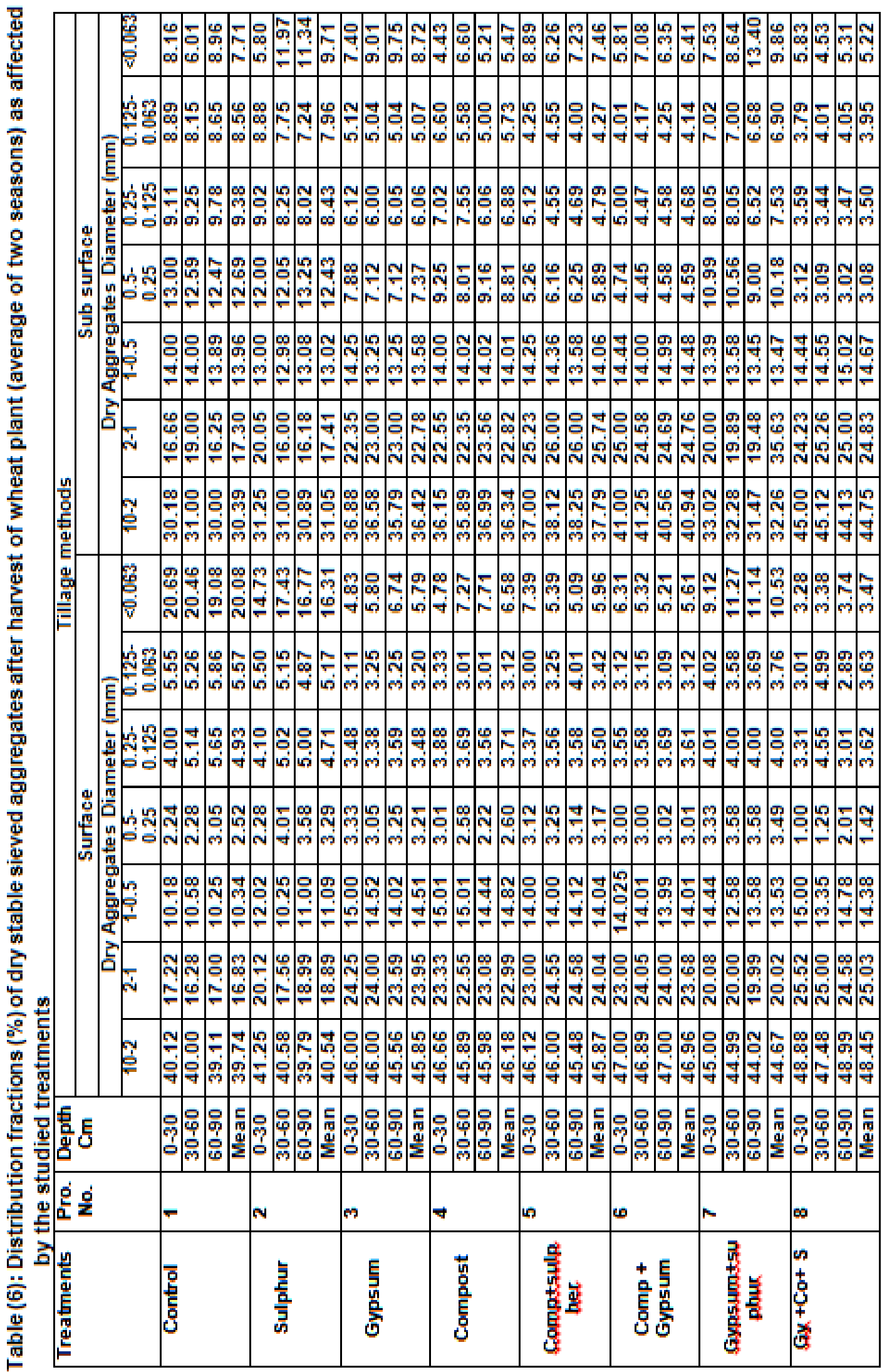


M. A. A. Esmaeil

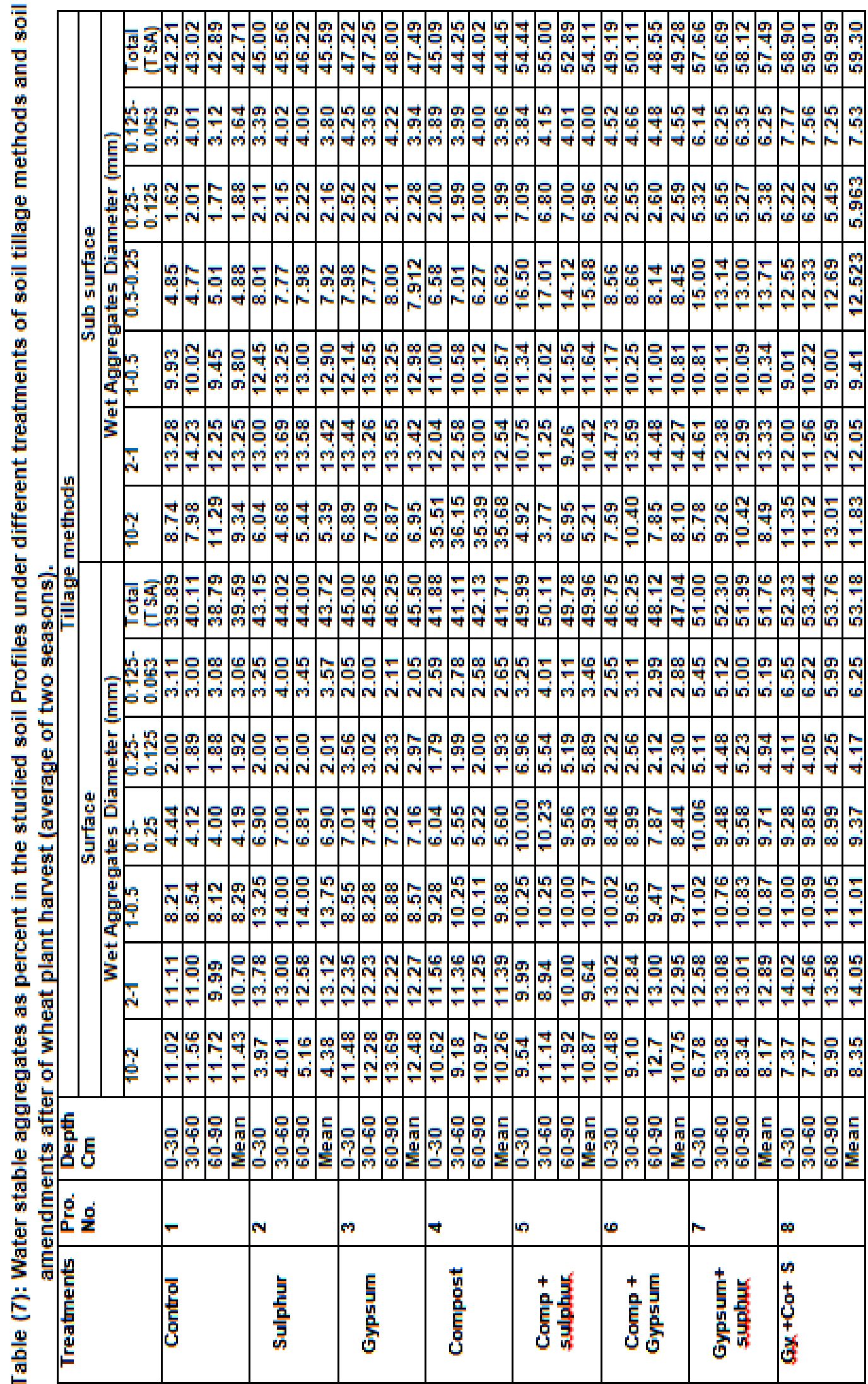


2 to 1 and 1 to $0.5 \mathrm{~mm}$ were higher than other aggregates fraction diameters in most treatments under study in surface and subsurface tillage. Concerning treatments of soil amendments, data showed that values of total stable aggregates were increased in all treatments under study compared to control. The highest increase in values of total stable aggregates was observed in the treatment of $\mathrm{Gy}+\mathrm{Co}+\mathrm{S}$ compared to other treatments and control. The effect of both tillage methods and soil amendments on soil WSA are in similar at all different soil depths. Similar results were obtained by Rasool et al. (2007) who concluded that, the application of organic matter in saline soil promotes flocculation of clay minerals, which is essential for the aggregation of soil particles and play an important role in erosion control. The added organic matter aid to glues the tiny soil particles together into larger water stable aggregates, increasing bio pores spaces which increase soil air circulation necessary for growth of plants and microorganisms. These results are in agreement with those of Fliessbach et al. (2000) who reported that organic soil management improved the soil structure by increasing soil aggregate. It is obvious from the data that, total stable aggregates were affected by tillage methods. The highest value of total stable aggregates was obtained in the subsurface tillage method. So, we can say that the subsurface tillage method improved soil total stable aggregates. Our results are in agreement with the results of Hossein et al. (2017).

\section{3.b.Soil hydraulic conductivity (HC):}

Hydraulic conductivity refers to the rate at which water flows through soil. For instance with, soils well-defined structure contain a large number of macro pores, cracks, and fissures which allow for relatively rapid flow of water through the soil. Data in Table (8) show that the values of hydraulic conductivity were low and increased by adding different treatments compared to control. Data indicated that the values of hydraulic conductivity were higher in subsurface tillage than those in surface tillage. The highest values of hydraulic conductivity were observed by applying $\mathrm{Gy}+\mathrm{Co}+\mathrm{S}$ treatment with subsurface tillage method compared to other treatments and control with different tillage methods. Hydraulic conductivity was varied significantly due to fertilization treatments and tillage methods. Similar results were obtained by Tayel and Abdel Hady (2005), who reported that soil EC and $\mathrm{pH}$ had a higher direct effect on HC value through negative relationship and described on the base of soil alkalinity. Our results are in agreement with the results of Alam et al. (2014) and Gholami et al. (2014).

\section{3.c. Soil bulk density (BD):}

Organic matter reduces soil bulk density through increasing aggregation. Data in Table (8) indicate that, the values of soil bulk density of different soil profiles of all treatments were relatively low and the maximum decrease exists in case of the treatment $\mathrm{Gy}+\mathrm{Co}+\mathrm{S}$ with subsurface tillage method compared to other treatments and control. This is probably due to the organic fraction is much lighter in weight than the mineral fraction in soils. These results are confirmed with the results of Brown and Cottone (2011), who observed that compost application influences soil structure in a beneficial way by lowering soil density as a result for the admixture of low density organic matter into the mineral soil fraction. In addition, the organic fraction is much lighter in weight than the mineral fraction in soils. Accordingly, the increase in the organic fraction decreases the total weight and bulk density of the soil. Soil bulk density 


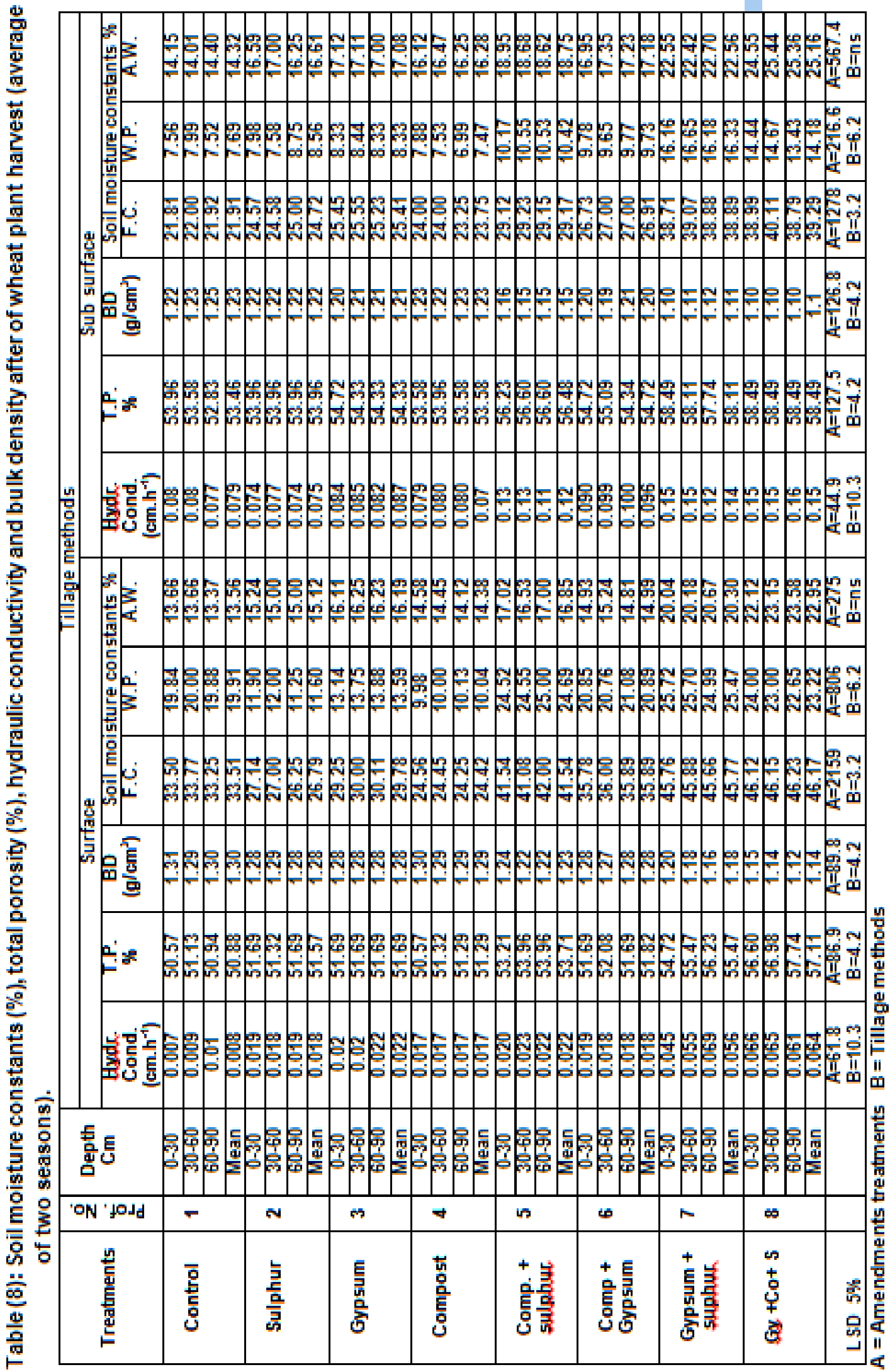


was varied significantly due to fertilization treatments and tillage methods. Similar results were obtained by Alam et al. (2014), who found a significance variance in bulk density due to different tillage methods. They said that the improved physical and chemical properties were recorded in the conservational tillage practices. Bulk and particle densities were decreased due to tillage practices.

\section{3.d. Total soil porosity (TP):}

Total soil porosity is a special formula which explains the relationship between both the soil real and bulk densities. On the other hand, it is an index of the relative volume of pores in soil. Data in Table (8) showed that total soil porosity increased and the maximum increase was found in the soil treated with $\mathrm{Gy}+\mathrm{Co}+\mathrm{S}$ with subsurface tillage method compared to other treatments and control with different tillage methods. These results are in agreement with the results of Hussain et al. (2001) who stated that physical properties like bulk density, porosity, water permeability and hydraulic conductivity were significantly improved when FYM (10 ton ha $^{-1}$ ) was applied in combination with chemical amendments, resulting in enhanced rice and wheat yields in sodic soil. Total soil porosity was varied significantly due to fertilization treatments and tillage methods and it was higher in subsurface tillage than in surface tillage. These results are confirmed with the results of Hossein et al. (2017).

\section{3.e. Soil moisture constants:}

The amount of water available to plant depends on two factors: the quantity of water that is able to infiltrate into the soil and the quantity of water that the soil is able to hold onto. Field capacity and available water holding capacity are influenced by the particle size, structure and content of
OM. However, clay soils, due to its higher matric potential and smaller pore size will generally hold significantly more water by weight than sandy soils. In this respect, data in Table (8) indicate that the values of available water were low. This may be attributed to high salinity levels of both irrigation water and soil, which leads to raising of osmotic pressure, and accordingly increase the soil retention moisture content at field capacity and wilting point. The increase of soil ESP increases the fine capillary pores (wilting point) compared with that of field capacity which leads to a decrease of the available water. The highest values of field capacity and available water were found in the treatment of $\mathrm{Gy}+\mathrm{Co}+\mathrm{S}$ with subsurface tillage method compared to other treatments and control with different tillage methods. Field capacity, wilting point and available water were varied significantly due to fertilization treatments and tillage methods, while there were no significance differences in values of available water only due to tillage methods. Similar results are also obtained through the work of Alam et al. (2014), who deduced a significant decrease in wilting point, while there was significant increase in total porosity and field capacity due to different tillage methods, and no significant variation in available water content.

\section{CONCLUSION}

Sulphur, Gypsum and compost applications improved physico-chemical characteristics of the salt affected soil and consequently increased grains and straw yields of wheat plant. Such improvements attributed to one or more of the following reasons: (1) The improvement of soil physical properties which is reflected on both water and nutrients behavior, (2) Lowering EC and $\mathrm{pH}$ of the treated soil through sulfur, gypsum and compost addition and (3) 
Improving soil chemical, biological and fertility properties. Generally, it can be concluded that gypsum, sulphur and compost application had decreased the hazardous effect of salinity of soil and hence exerted favorable effects on growth and yield of wheat. Subsurface tillage method improved soil chemical and physical properties which are reflected on growth and grain yield of wheat compared with the surface tillage method.

\section{REFERENCES}

Abd Elrahman, Sh. H., M.A.M. Mostafa, T.A. Taha, M.A.O. Elsharawy and M.A. Eid (2012). Effect of different amendments on soil chemical characteristics, grain yield and elemental content of wheat plants grown on salt-affected soil irrigated with low quality water. Annals of Agricultural Science 57(2): 175-182.

Abdallah, M., L. Dubousset, F. Meuriot, P. Etienne, J.C. Avice and A. Ourry (2010). Effect of mineral sulphur availability on nitrogen and sulphur uptake and remobilization during the vegetative growth of Brassica napus L. J. Exp. Bot., 61(10):2335-2346.

Abou El-Defan, T.A., I.M.M. El-Banna, T.A. El-Maghraby, M.E. Abdallah and M.M. Selem (2005). Efficiency of some amendments added to clayey soil irrigated with drainage water. J. Agric. Sci., Mansoura Univ. 30: 3479-3489.

Ahmed, K., G. Qadir, A.R. Jami, A.l. Saqib, M.Q. Nawaz, M.A. Kamal and E. Haq (2016). Strategies for Soil Amelioration Using Sulphur in Salt Affected Soils. Cercetări Agronomice în Moldova, Vol. XLIX , No. 3 (167): 516.

Ahmed, K., G. Qadir, A.R. Jami, A.I. Saqib, M.Q. Nawaz, M.A. Kamal and E. Haq (2017). Comparative Reclamation Efficiency of Gypsum and Sulfur for Improvement of Salt Affected.
Bulgarian Journal of Agricultural Science, 23 (1): 126-133.

Alam, K., M. Islam, N. Salahin and M. Hasanuzzaman (2014). Effect of Tillage Practices on Soil Properties and Crop Productivity in Wheat-Mungbean-Rice Cropping System under Subtropical Climatic Conditions, The Scientific World Journal, Volume 2014, Article ID 437283, 15 pages.

Beheiry, G., S. Gh and A.A. Soliman (2005). Wheat productivity in previously organic treated calcareous soil irrigated with saline water. Egypt J. Appl. Sci., 20: 363-376.

Bello, W.B. (2012). Influence of gypsum application on wheat (Triticum aestivum) yield and components on saline and alkaline soils of Tigray region, Ethiopia. Greener J. of Agric. Sci., 2: $316-322$.

Brady, N.C. and R.R. Weil (2005). The Nature and Properties of Soils, 14th Edition.

Brown, S. and M.Cottone, (2011). Changes in Soil Properties and Carbon Content Following Compost Application: Results of On-farm Sampling. Compost Science and Utilization, Vol.

Cottenie, A., M. Verloo, L. Kiekens, G. Velghe and R. Camerlynck (1982). "Chemical Analysis of Plants and Soils". Laboratory of Analytical and Agrochemistry, State Univ., Ghent, Belgium.

El-Banna, I.M.M., T.A. Abou El-Defan, M.M.I. Selem and T.A. El-Maghraby (2004). Potassium fertilization and soil amendments interactions and their effects on wheat irrigated with different water qualities. J. Agric. Sci., Mansoura Univ. 29: 5953-5963.

Elgezairie, M. Kh. (2016). Effect of organic additives on efficiency of sulphur fertilization. M.Sc. Thesis, Fac. Of Agric. Menoufia Univ. Shebin El-Kom, Egypt. 
El-Habbasha, S.F., M.M. Tawfik and Magda H. Mohamed (2008). Response of two wheat varieties to partial replacement of recommended nitrogen fertilizer by bacterial inoculations. Egypt. J. Agron., 30(2): 187- 200.

El-Maaz, E.I.M., H.M.R.M. Ahmed and Kh. A. Shaban (2014). Soil chemical properties and wheat productivity as affected by organic, biofertilization and cultivation methods in saline soil. Minufiya, J. Agric. Res., 39 (6): 19551968.

El-Sanat, G.M.A. (2003). Effect of amelioration processes on nutrients status in salt affected soil. M.Sc. Thesis, Fac. Of Agric., Menoufia Univ., Shebin El-Kom, Egypt.

Fliessbach, A., P. Mader, D. Dubois and L. Gunst (2000). Results from a 21 years old field trial. Organic farming Enhance Soil Fertility and Biodiviersity Fi BI Dossier N1, 15, pp19.

Gee, G.W. and J. W. Bauder (1986). Particle size analysis in Methods of Soil Analysis (Klute, Ed. Part1. Agron.9. 15 :383- 409. Am. Soc. Agron. Madison. Wisconsin . U.S.A).

Gholami, A., H. R. Asgari and Z. Saeidifar (2014). Short-term effect of different tillage systems on soil salinity, density and nutrients in irrigated wheat. International journal of Advanced Biological and Biomedical Research, 2 (5): 1513-1524.

Gomez, K.A. and A.A. Gomez (1984). Statistical Procedures for Agriculture Research (2 ed.) John Wiley and Sons Inc. New York.

Hossein, T., G. Cayci and K.A. Rezaeieh (2017). The effects of tillage methods on soil aggregation and crop yields in a wheat-corn rotation under semi-arid conditions. Solid Earth Discuss., doi:10.5194/se-2017-13, 2017.

Hussain, N., G. Hassan, M. Arshadullah and F. Mujeeb (2001). Evaluation of amendments for the improvement of physical properties of sodic soil. Intl. J. Agric. Bio., 3:319-322.

Ibrahim, S. A. (1964). Studies of the size distribution of water stable aggregates in the soil of the Nile Delta. M. Sc. Thesis, Fac. of Agric., Ain-Shams Univ., Egypt.

Jez J., (2008). Sulfur: a missing link between soils, crops and nutrition. Agronomy Monograph no.50, Am. Soc. Agron, Crop Sci. Soc Am., Soil Sci. Soc. Am., p. 323.

Khurshid, K., M. Iqbal, M.S. Arif and A. Nawaz (2006). "Effect of tillage and mulch on soil physical properties and growth of maize," International Journal of Agriculture and Biology, 8: 593-596.

Lal R. (1993). Tillage effects on soil degradation, soil resilience, soil quality, and sustainability, Soil and Tillage Research, 27 (1-4): 1-8.

Mahmood, A.M., N. Yazdanpanah, L.R. Sinobas, E. Pazira and A. Neshat (2013). Reclamation of calcareous saline sodic soil with different amendments (I): Redistribution of soluble cations within the soil profile. Agric. Water Management 120:30 - 38.

Mohammadi, K., A. Rokhzadi, S. Saberali, M. Byzedi and M. Nezhad (2013). Tillage effects on soil properties and wheat cultivars traits. Archives of Agronomy and Soil Science, 59 (12): 1625-1641.

Moustafa, F.A.F. (2005). Studies on reclamation of saline sodic soils. PhD Thesis, Fac. Agric., Benha Univ., Egypt, pp. 35-60.

Muhammad, D. and R.A. Khattak (2009). Growth and nutrient concentration of maize in pressmud treated salinesodic soils. Soil Environ., 28:145-155.

Rasool, R., S.S. Kukal and G.S. Hira (2007). Soil physical fertility and crop performance as affected by long term application of FYM and inorganic fertilizers in rice-wheat 
system, Soil Till. Res. 96: 64-72.

Rasouli, F., S. Afzalinia, P.A. Kiani and M. Alavimanesh (2014). Effect of different tillage on soil properties and wheat yield in saline condition of temperate region of Fars province. Agricultural Scientific Information and Documentation Centre, Agricultural Research and Education Organization.

Richards, A.L. (1947). Pressure membrane apparatus construction and Use. Agric. Enger., 28: 451-454.

Richards, A.L. and I.R. Weaver (1944). Moisture retention by some irrigated soils as related to soil moisture tension. J. Agric. Res., 29:215-235.

Richards, A.L. (1954). Diagnosis and Improvement of Saline and Alkali Soils U.S. Dept. Agric. Hand Book. No 60, U.S.Covt. Print. Office, Washington, D.C.

Singh, S.P., P.N. Takkar and V.K. Nayyar (1989). Effect of $\mathrm{Cd}$ on wheat as influenced by lime and manure and its toxic level in plant and soil. Int. $J$. Environ. Stud. 33: 59-66.

Stakman, W.P. and G.G. Vanderhast (1962). The use of the pressure membrane apparatus to determine soil moisture constants at P.F 3.0 to 4.2 inclusive. Institute for Land and Water Management Research, Note No. 139.
Szaboles, I. (1989). Salt Affected Soils. CRC Press Inc., Boca Raton, Florida, USA.

Tarek, M.A.S., N.E. El-Keltawi, M.A. Khan, M. Nan and L.J. Zhao (2013). Plant growth and flowering of cape jasmine (Gardenia jasminoides Ellis) in various substrates amended with sulphur. Global Journal of Plant Ecophysiology, 3(2): 36-43.

Tayel, M.Y. and M. Abdel Hady (2005). Water movement under saturated and unsaturated flow in coarse textured soils under Baharia Oasis Conditions. Egypt. J. Appl. Sci., 20(6A): 358-370.

Yoder, R.E. (1936). A direct method of aggregate analysis of soils and a study of the physical nature of erosion losses. J. Amer. Soc. Agron., 28: 337351.

Zeidan, E.M., I.M. Abd El-Hameed, A.H. Bassiouny and A.A. Waly (2009). Effect of irrigation intervals, nitrogen and organic fertilization on yield, yield attributes and crude protein content of some wheat cultivars under newly reclaimed saline soil condition. 4th Conference on Recent Technologies in Agriculture. 
تأثير إضافة الكبريت والجبس والكمبوست ونظم الحرث على خواص الأرض وإنتاجية القمح فى أرض ملحية

\author{
محمود عبدالجواد أحمد إسماعيل
}

معهز بحوث الأراضى والمياه والبيئة ، مركز البحوث الزراعية ، الجيزة ، مصر الجمر

الملخص العربى

إدارة الأرض المتأثرة بالأملاح تتطلب تطوير فى تكنولوجيا الإستصلاح واستخدام الأساليب الأكثر كفاءة للحصول على أفضل إنتاجية للمحاصيل. يوجد العديد من المعالجات التى يمكن استخدامها لاستصلاح الأاضى الملحية ولكن استعمال كل معالج يتوقف على تكلفته وتوفره والوقت المناسب لاستخدامه. تم إجراء تجرية حقلية فى موسمين شتويين متتاليين 2015/2014 و 2016/2015 فى مزرعة محطة البحوث الزراعية بسهل الحسينية بمحافظة الثرقية ، مصر وذلك لاراسة وتقييم تأثير طرق حرث مختلفة (سطحى وتحت سطحى) ومصادر تسميد مختلفة (الكبريت ، الجبس ، الكمبوست ، الكمبوست+ الكبريت ، الكمبوست+|لجبس ، الجبس+الكبريت والجبس+(الكمبوست+الكبريت) على بعض خواص الأرض وإنتاجية القمح. تم استخلام تصميم قطاعات منثقة فى التجريتين.

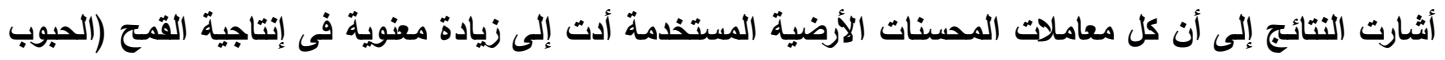
والقش) مقارنة بالكتترول. وسجلت أكبر زيادة فى حبوب وقش القمح عند استخام المعاملة الجبس+الكمبوست+|الكبريت فى الحرث التحت سطحى مقارنة بياقي المعاملات والكنترول مع استخدام طرق الحرث المختلفة. أدت المعاملات المستخدمة أيضاً إلى انخفاض قيم التوصيل الكهربى (EC) وحموضة التربة (pH) وزيادة فى قيم المادة العضوية والسعة التبادلية الكاتيونية للترية، وكان التأثير اكثر وضوحاً ومعنوية فى معاملة الجبس+الكمبوست+ الكبريت الكبريت. أدي استخدام الحرث التحت سطحي الي حدوث تحسن ملحوظ في الخواص الكيميائية عن الحرث السطحي .

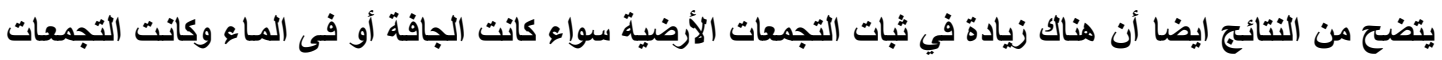
أكثر ثباتـا فى حالـة الأرض المعاملة بالجبس+الكمبوست+الكبريت فـ الحرث التحت سطحى مقارنـة ببـاقي المعاملات والكنترول مـع استخلام طرق الحرث المختلفة. أدى استخلام المعاملة الجبس+الكمبوست+الكبريت إلى زيادة التوصيل

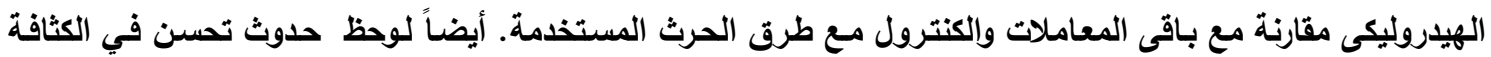
الظاهريـة وزادت المسـامية الكلية وكذلك ازدادت قيم ثوابت الرطوبـة عند كل من السـعة الحقلية والمساء الميسر نتيجـة المعاملة بالجبس+الكمبوست+الكبريت فى الحرث التحت سطحى مقارنة بباقي المعاملات والكنترول مـع استخدام طرق

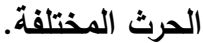
* ويصفة عامـة، يمكن استتناج أن إضـافة الجبس والكبريت والكمبوست أدت السي تحسين خواص التربـة الكيميائيسة

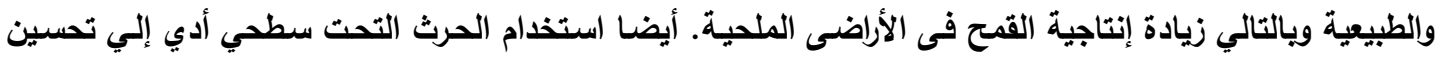

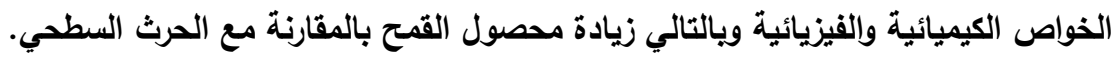

أسماء السادة المحكمين

معهة بحوث الأراضى والمياه والبيئة

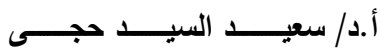

كلية الزراعة - جامعة المنوفية

أ.د/ الحسينى عبدالفغار أبوحسين 
